\title{
Pterocarpus Marsupium for the Treatment of Diabetes and Other Disorders
}

\author{
Dhayaney Vijayan and Sibi G* \\ Department of Biotechnology, Indian Academy Degree College-Autonomous, India
}

Submission: January 24,2019; Published: March 01, 2019

*Corresponding author: Sibi G, Head of the Department, Department of Biotechnology, Indian Academy Degree College-Autonomous, Bangalore, India

\begin{abstract}
Pterocarpus marsupium Roxb., is a deciduous tree commonly grows in India and Sri Lanka. It is well known to Ayurvedic medicine because of its curative and lenitive properties. The heartwood extract of $P$. marsupium is reported to have many pharmacological compounds and used in treatment of various disorders. Literature was collected via electronic search (PubMed, ScienceDirect) from published articles that reports medicinal properties of $P$. marsupium. A significant research of antidiabetic activities and other medicinal properties of $P$. marsupium combined with bioactive compounds isolated from the plant will provide leads for the discovery of new drugs for the management of many disorders with minimal side effects.
\end{abstract}

Keywords: Pterocarpus marsupium; Vijayasar; Anti-diabetic; Antioxidant

\section{Introduction}

Diabetes is a chronic disorder of carbohydrate, fat and protein metabolism characterized by increased fasting and post prandial blood sugar levels. The increasing worldwide incidence of diabetes mellitus in adults constitutes a global public health burden. Out of the two types of diabetes, the incidence of noninsulin dependent diabetes mellitus is much higher than the insulin dependent diabetes mellitus. Even insulin therapy does not reinstate a permanent normal pattern of glucose homeostasis and carries an increased risk of atherogenesis and hypoglycemia. Plants are used as traditional remedies in one or other form for the treatment of diabetes. There has been an exponential growth in the field of herbal medicine and these drugs are gaining popularity both in developing and developed countries because of their natural origin and less side effects. Drugs derived from natural products have played a major role in the development of pharmaceutical treatments for diabetes. Pterocarpus marsupium Roxb., is a deciduous tree commonly grows in Sri Lanka and India [1]. It is popularly known as Vijaysar in Hindi and is a valuable medicinal plant, used mainly in Ayurveda, for the treatment of diabetes [2-4]. It is well known to Ayurvedic medicine because of its curative and lenitive properties. Its flowers are employed against fever, its heartwood as depurative, hemostatic, and rejuvenating, its wood is used for chest and body pain as well as indigestion, etc. The gum (kino) obtained from the tree is used in diarrhea, pyrosis and toothache. Bruised leaves are used externally for boils, sores, and various skin diseases. The water kept in tumblers made out of the wood of this plant is said to be beneficial for chest pain and diabetes. The bark of P. marsupium is very effective in preventing cataract formation and reducing hyperglycemia in alloxanized diabetic rats [1] and the heartwood is useful as hypolglycemic agents [5].

\section{Methodology}

A systematic search was carried out in Pub Med, Scopus and Web of Sciences using a combination of Boolean operators. Peer reviewed papers in English on the keyword Pterocarpus marsupium were retrieved and evaluated based on titles and abstracts. The retrieved papers were managed using Mendeley and the data were consolidated.

\section{Anti-diabetic activity}

Aqueous extract of heartwood of Pterocarpus marsupium was given orally to alloxan induced type- 2 diabetic rabbit model (Pradhan et al., 2017). Both the fasting blood glucose (194.8 \pm 12.7 vs. $155.2 \pm 16.3$ ) and postprandial blood glucose $(191.6 \pm 23.2$ vs. $149.2 \pm 14.5)$ were decreased indicating the hypoglycaemic effect of $P$. marsupium. Incubation of red blood cells with glucose in the presence of alcoholic extract of $P$. marsupium under high glucose conditions lead to reduction in the accumulation of intracellular sorbitol in a dose dependent manner. There was $50 \%$ reduction of sorbitol accumulation with alcoholic extract of was observed with IC50 151.00 $\mu \mathrm{g} /$ $\mathrm{ml}$ and $105.12 \mu \mathrm{g} / \mathrm{ml}$ for ascorbic acid [6]. Ethanolic extract of $P$. marsupium heartwood have antihyperglycemic activity in streptozotocin treated diabetic rats [7]. At $100 \mathrm{mg} / \mathrm{kg}$ dose levels, fasting blood glucose, oral glucose tolerance and serum insulin levels were recorded as $113 \pm 3.40 \mathrm{mg} / \mathrm{dl}, 35930 \pm 102.9$ 
AUC and $160 \pm 31.3 \mathrm{ng} / \mathrm{l}$ respectively. Blood glucose lowering effect of $P$. marsupium heartwood was also reported. Antidiabetic activity of $P$. marsupium Roxb. heartwood in alloxan induced diabetic rats using extracts obtained by optimized conventional and non-conventional extraction methods was evaluated by Devgan et al. [8]. Ultrasound-assisted extraction was proved to enhance the antidiabetic activity of $P$. marsupium. Mohan Kumar et al. [9] reported that the exposure of mouse pancreatic and muscle tissues to $P$. marsupium extract stimulated the insulin secretion and glucose uptake, respectively, in a concentration-dependent manner. Gairola et al. [10] found that the aqueous extract significantly reduces type 2 diabetes in rats and can prevent hyperinsulinemia and hypertriglyceridemia. Aqueous extract of $P$. marsupium has significantly decreased the fasting blood glucose $(182.5 \pm 4.1 \mathrm{mg} / \mathrm{dL})$ in type 2 diabetic rat. It also decreased the postprandial hyperglycemia significantly $(112.3 \pm 2.8 \mathrm{mg} / \mathrm{dL})$ as compared to diabetic control group $(301.4 \pm 5 \mathrm{mg} / \mathrm{dL})$. P. marsupium modulated the inflammatory cytokine TNF- $\alpha$ in type 2 diabetic rats [11]. Dhanabal et al. [12] studied the antidiabetic activity of various subfractions of the alcohol extract of the bark of Pterocarpus marsupium Roxb. in alloxan-induced diabetic rats. The butanol subfraction of the alcohol extract of $P$. marsupium exhibits significant antidiabetic activity and corrects the metabolic alterations in diabetic rats. Mukhtar et al. [13] reported the hypoglycemic activity of $P$. marsupium wood at an oral dose of $250 \mathrm{mg} / \mathrm{kg}$ in alloxan induced diabetic rats. The aqueous extract of $P$. marsupium significantly $(\mathrm{P}<0.001)$ reduced the blood sugar levels from $72.32 \pm 5.62$ to $61.35 \pm 1.2 \mathrm{mg} \% 2 \mathrm{~h}$ after oral administration of the extract and also significantly lowered the blood glucose in alloxan diabetic rats from $202.91 \pm 5.44$ to $85.22 \pm 11.28 \mathrm{mg} \% 21$ days after daily oral administration of the extract [14]. Alloxan-diabetic rats fed with the ethanolic extract of P. marsupium wood for 5 days resulted in a significant lowering of fasting blood sugar level. There was a 5-fold increase in blood glucose level of alloxan to rats after injection compared to normal controls and feeding of the extract to alloxan-diabetic animals lowered the blood sugar by $70 \%$ as compared to the alloxan-diabetic controls [15].

\section{Antioxidant activity}

Many recent studies reveal that antioxidants capable of neutralizing free radicals are effective in preventing experimentally induced diabetes in animal models. In DPPH scavenging activity and ABTS-+ scavenging activity, IC50 values were found to be $138.3,12.4,13.5$ and $47.8,3.9,4.2 \mu \mathrm{g} / \mathrm{mL}$ for aqueous, methanolic extract of $P$. marsupium and standard ascorbic acid respectively. In $\alpha$-amylase inhibition assay and $\alpha$-glucosidase inhibition assay, IC50 values for standard Acarbose, aqueous and methanolic extract of heartwood were $44.09,166.72,48.20$ and $45.17,172.32,48.12$ respectively [16]. The effects of different fractions of heart wood of Pterocarpus marsupium on antioxidant enzyme like protein thiols and the efficacy of the extract for the protection of the renal function in alloxan induced diabetic rats was evaluated by Bhata, Nayak [17].
P. marsupium extract showed a promising antioxidant effect, as well as hypoglycemic activity. Aqueous extract of $P$. marsupium showed high antioxidant activity in all different assays used and also protected mitochondria against oxidative damage. It significantly reduced lactate dehydrogenase release along with reduction of lipid peroxidation [18]. The herbal extract mixture of $P$. marsupium and 0 . sanctum has succeeded in not only rectifying dyslipidemia but also in restoring the endogenous antioxidant levels to the pre-diabetic status in non-diabetic and alloxan induced diabetic adult female Wistar rats [19].

\section{Anticancer activity}

The cytotoxicity of $P$. marsupium aqueous extract was evaluated by Gosetti et al. [20] using calcein acetoxymethyl ester (calcein-AM) assays. Different cell lines were incubated for $24 \mathrm{~h}$ with different concentrations of the aqueous heartwood extract. The IC50 values for cancer cells are comparable among the cell lines and are significantly lower (at least 50\%) for the cancer cell lines than for non-tumoral cell lines, highlighting a selective cytotoxicity of the extract towards the cancer cells. $\alpha$-dihydroxychalcone-glycoside $(\alpha$-DHC) isolated from $P$. marsupium has effectively reduced nitric oxide and cytokine production by the LPS stimulated RAW 264.7 mouse macrophage cell line. The compound effectively attenuated the expression of inflammation-mediating enzymes COX-2 and iNOS at the mRNA as well as protein levels in a concentration dependent manner [21]. Pterostilbene isolated from P. marsupium was found to cause apoptosis in breast (MCF-7) and prostate (PC3) cancer cell lines. It also inhibited Matrix metalloproteinase 9 (MMP9) and $\alpha$-methylacyl-CoA recemase (AMACR), two very well-known metastasis inducers [22].

\section{Reproductive effects}

Hugar et al. [23] has reported that Pterocarpus marsupium showed potential reproductive effects on testosterone propionate induced Polycystic Ovary Syndrome (PCOS) female albino rats and could be used as an alternative therapy in the treatment of PCOS.

\section{Activity against cataract}

The protective effect of Pterocarpus marsupium bark extracts against cataract in streptozotocin-induced diabetic male albino rats was investigated by $\mathrm{Xu}$ et al. [24]. The blood glucose was reduced up to $36 \%$ following treatment with bark extracts. The blood insulin and tissue GSH contents were substantially increased more than $100 \%$ in diabetic rats following treatment with extracts. Aldose reductase activity was reduced up to $79.3 \%$ in diabetic rats following treatment with extracts. he findings concluded that the use of $P$. marsupium bark extracts could be the potential therapeutic approach for the reduction of aldose reductase against diabetic cataract.

\section{Activity against Ulcerative colitis}

The effect of $P$. marsupium on acetic acid induced ulcerative colitis in rats was studied by Mathew et al. [25]. P. marsupium 


\section{Journal of Complementary Medicine \& Alternative Healthcare}

had significantly reduced colon inflammation and mucosal damage in the treated group. The COX-1/2 selective inhibitory activity of $P$. Marsupium (PM) extract was investigated by Hougee et al. [26]. PM extract, pterostilbene and resveratrol inhibited PGE2 production from LPS-stimulated human Peripheral Blood

Table 1: Pharmacological Activity of Pterocarpus marsupium

\begin{tabular}{|c|c|}
\hline Activity & References \\
\hline Antidiabetic & Sheehan et al. [5] \\
\hline Anti-diabetic & Jahromi et al. [28] \\
\hline Anti-hyperlipidemic & Manickam et al. [29] \\
\hline Anti-hyperglycemic & Vat et al. [14] \\
\hline Antihyperglycemic & Dhanabal et al. [12] \\
\hline Hypoglycemic property & Hougee et al. [26] \\
\hline CoX-2 inhibition & Devipriya et al. [30] \\
\hline Hepatoprotective & Mohire et al. [31] \\
\hline Cardiotonic & Karanjit et al. [32] \\
\hline Hypoglycemic property & Badkhane et al. [33] \\
\hline Regeneration of beta cells in pancreas & Halagappa et al. [11] \\
\hline Anti-diabetic & Patil and Dattatraya [34] \\
\hline Antihyperglycemic & Waghmare et al. [35] \\
\hline Antihyperglycemic & Rizvi and Mishra [36] \\
\hline Astringent property & Devgan et al. [8] \\
\hline Antidiabetic & Khan et al. [37] \\
\hline Regeneration of beta cells in pancreas & Hilal, Kalyanaraman [38] \\
\hline Antihyperlipidemic & Pradhan et al. [39] \\
\hline Hypoglycaemic & Singh et al. [40] \\
\hline In-vitro lipid lowering & \\
\hline
\end{tabular}

Table 2: Bioactive Compounds isolated from Pterocarpus marsupium.

\begin{tabular}{|c|c|}
\hline Isolated compound & References \\
\hline Pterostilbene & Haranath et al. [41] \\
\hline 5,4'-dimethoxy-8-methylisoflavonen (Isoflavone) & Mitra and Joshi [42] \\
\hline $\begin{array}{l}\text { selin-4(15)-en-1 } \beta, 11 \text {-diol, } \beta \text {-eudesmol, erythrodiol-3-monoacetate and pterostilbene (sesquiterpene } \\
\text { alcohol) }\end{array}$ & Adinarayana, Syamasundar [43] \\
\hline Epicatechin & Sheehan et al. [5] \\
\hline Epicatechin & Chakravarthy, Gode [44] \\
\hline $\begin{array}{l}\text { 7-Hydroxy-6, 8-dimethyl flavanone-7-0-alpha-L-arabinopyranoside and 7,8,4'-trihydroxy-3', } \\
\text { 5'-dimethoxy flavanone-4'-O-beta-D-glucopyranoside }\end{array}$ & Tripathi, Joshi [45] \\
\hline $\begin{array}{c}\text { 4,6,4'-trihydroxyaurone 6-0-rhamnopyranoside, 4,6,4'-trihydroxy-7-methylaurone } \\
\text { 4-0-rhamnopyranoside (Aurone glycosides) }\end{array}$ & Mohan, Joshi [46] \\
\hline Marsupsin, pterosupin, pterostilbene and liquiritigenin & Jahromi et al. [28] \\
\hline Marsupsin, pterosupin, pterostilbene and liquiritigenin & Manickam et al. [29] \\
\hline 6-hydroxy-7-0-methyl-3-(3-hydroxy-4-0-methyl benzyl) chronan-4-one (Homoisofalvonoid) & Jain et al. [47] \\
\hline 2-hydroxy-2-benzylcoumaranone & Mathew, Subba Rao [48] \\
\hline 6-hydroxy-3,5,7,4'-tetramethoxyflavone 6-rhamnoside (flavonol glycoside) & Yadav, Singh [49] \\
\hline Pterocarposide & Handa et al. [50] \\
\hline Flavonoid C-glycosides & Maurya et al. [51] \\
\hline 7-0-alpha-L-rhamnopyranosyl oxy-4'-methoxy-5-hydroxy isoflavone & Anandharajan et al. [52] \\
\hline Pterostilbene & Chakraborty et al. [22] \\
\hline Pterolinus K and pterolinus L (phenanthrenedione and chalcone) & Wu et al. [53] \\
\hline
\end{tabular}

Mononuclear Cells (PBMC) with IC50 values of $3.2+/-1.3$ microg/ $\mathrm{mL}, 1.0+/-0.6$ micro $\mathrm{M}$ and $3.2+/-1.4$ micro $\mathrm{M}$, respectively. In a COX-1 Whole Blood Assay (WBA) PM extract was not effective while in a COX-2 WBA, PM extract decreased PGE2 production indicating COX-2 specific inhibition (Table 1 \& Table 2) [27-56]. 
Journal of Complementary Medicine \& Alternative Healthcare

\begin{tabular}{|c|c|}
\hline Marsupsin, pterocarpin & Thara et al. [54] \\
\hline Bijayasaline & Joshi et al. [55] \\
\hline$\alpha$-Dihydroxychalcone-glycoside & Chakraborty et al. [21] \\
\hline Volatile compounds & Gosetti et al. [20] \\
\hline 3'-Hydroxypterostilbene & Yadav, Mishra [16] \\
\hline Liquiritigenin & Singh et al. [40] \\
\hline Marsuposide & \\
\hline
\end{tabular}

\section{Conclusion}

Major hindrance in amalgamation of herbal medicine in modern medical practices is lack of scientific and clinical data proving their efficacy and safety. This review article showed the anti-diabetic potential of a P. Marsupium for the management of hyperglycemia, along with good antioxidant activity. However limited data were available about the collective pharmaceutical property of $P$. Marsupium. This plant may provide leads for the discovery of new drugs for the management of many disorders with minimal side effects.

\section{References}

1. Therrell MD, Stahle DW, Mukelabai MM, Shugart HH (2007) Age, and radial growth dynamics of Pterocarpus angolensis in southern Africa. For Ecol Manage 244: 24-31.

2. Chatterjee A, Pakrashi SC (1991) The treatise on Indian medicinal plants: vol. 1. New Delhi: Publications and Information Directorate, CSIR 172p.-illus., col. illus. ISBN 8172360118 En Icones. Includes authentic Sanskrit slokas in both Devnagri and Roman scripts. Plant Rec Geogr: 6.

3. Satyavati GV, Gupta AK, Tandon N (1987) Med Plants India 27: 574-575.

4. Satyavati GV, Neeraj T, Madhu S (1989) Indigenous plant drugs for diabetes mellitus. Indian J Diabetes Dev Countries: 1-35.

5. Sheehan EW, Zemaitis MA, Slatkin DJ, Schiff (1983) A constituent of Pterocarpus marsupium, (-)-epicatechin, as a potential antidiabetic agent. J Nat Prod 46 (2): 232-234.

6. Gupta P, Jain V, Pareek A, Kumari P, Singh R, et al. (2017) Evaluation of effect of alcoholic extract of heartwood of Pterocarpus marsupium on in vitro antioxidant, anti-glycation, sorbitol accumulation and inhibition of aldose reductase activity. J Tradit Complement Med 7(3): 307-314.

7. Mishra A, Srivatsava R, Srivatsava SP, Gautam S, Tamrakar AK, et al. (2013) Antidiabetic activity of heartwood of Pterocarpus marsupium Roxb. and analysis of phytoconstituents. Indian Journal of Experimental Biology 51(5): 363-374.

8. Devgan M, Nanda A, Ansari SH (2013) Comparative evaluation of the anti-diabetic activity of Pterocarpus marsupium Roxb. heartwood in alloxan induced diabetic rats using extracts obtained by optimized conventional and non-conventional extraction methods. Pak J Pharm Sci 26(5): 973-976.

9. Mohan Kumar SK, Oshea T, McFarlane JR (2012) Insulinotrophic and insulin-like effects of a high molecular weight aqueous extract of Pterocarpus marsupium Roxb. hardwood. Journal of Ethnopharmacology 141(1): 72-79.

10. Gairola S, Gupta V, Baljinder S, Mukesh M, Parveen B (2010) Phytochemistry and pharmacological activities of Pterocarpus marsupium - a review. Int Res J Pharm 1: 100-104.

11. Halagappa K, Girish HN, Srinivasan BP (2010) The study of aqueous extract of Pterocarpus marsupium Roxb. on cytokine TNF- $\alpha$ in type 2 diabetic rats. Indian Journal of pharmacology 42(6): 392-396.

12. Dhanabal SP, CK Kokate, Ramanathan M, Kumar EP, Suresh B (2005) Hypoglycaemic activity of Pterocarpus marsupium Roxb. Phytother Res 20(1): 4-8.

13. Mukhtar HM, Ansari SH, Ali M, Bhat ZA, Naved T (2006) Effect of aqueous extract of Pterocarpus marsupium wood on alloxan-induced diabetic rats. Pharmazie 60(6): 478-479.

14. Vats V, Grover JK, Rathi SS (2002) Evaluation of antihyperglycemic and hypoglycemic effect of Trigonella foenum-graecum Linn, Ocimum sanctum Linn and Pterocarpus marsupium Linn in normal and alloxanized diabetic rats. J Ethnopharmacol 79(1): 95-100.

15. Ahmad F, Khalid P, Khan MM, Chaubey M, Rastogi K, et al. (1991) Hypoglycemic activity of Pterocarpus marsupium wood. Journal of Ethnopharmacology 35(1): 71-75.

16. Yadav VK, Mishra A (2018) In vitro and in silico study of hypoglycemic potential of Pterocarpus marsupium heartwood extract. Nat Prod Res: $1-5$.

17. Bhata V, Nayak BS (2015) Renoprotective effects, protein thiols and liver glycogen content of alloxan-induced diabetic rats treated with different fractions of heartwood of Pterocarpus marsupium. Nat Prod Commun 10(11): 1843-1846.

18. Mohammadi M, Khole S, Devasagayam TP, Ghaskadbi SS (2009) Pterocarpus marsupium extract reveals strong in vitro antioxidant activity. Drug Discov Ther 3(4): 151-161.

19. Singh PK, Baxi D, Banerjee S, Ramachandran AV (2012) Therapy with methanolic extract of Pterocarpus marsupium Roxb and Ocimum sanctum Linn reverses dyslipidemia and oxidative stress in alloxan induced type I diabetic rat model. Experimental and Toxicologic Pathology 64 (5): 441-448.

20. Gosetti F, Chiuminatto U, Martinotti S, Bolfi B, Ranzato E, et al. (2016) Characterization of the volatile and nonvolatile fractions of heartwood aqueous extract from Pterocarpus marsupium and evaluation of its cytotoxicity against cancer cell lines. Planta Medica, 82(14): 1295-1301.

21. Chakraborty P, Saraswat G, Kabir SN (2014) $\alpha$-Dihydroxychalcone-glycoside $(\alpha$-DHC) isolated from the heartwood of Pterocarpus marsupium inhibits LPS induced MAPK activation and up regulates HO-1 expression in murine RAW 264.7 macrophage. Toxicol Appl Pharmacol 277(1): 95-107.

22. Chakraborty A, Gupta N, Ghosh K, Roy P (2010) In vitro evaluation of the cytotoxic, anti-proliferative and anti-oxidant properties of pterostilbene isolated from Pterocarpus marsupium. Toxicology in vitro 24(4): 1215-1228.

23. Hugar AL, Kanjikar AP, Londonkar RL (2017) A novel potential reproductive effects of Pterocarpus marsupium Methanolic extract on testosterone propionate induced polycystic ovary syndrome in female albino rats. Endocr Metab Immune Disord Drug Targets 17(4): 317-323.

24. Xu Y, Zhao Y, Sui Y, Lei X (2018) Protective effect of Pterocarpus marsupium bark extracts against cataract through the inhibition of aldose reductase activity in streptozotocin-induced diabetic male albino rats. 3 Biotech 8(4): 188 
25. Mathew MM, Han NV, Murugesan A, Raj EA, Prashanth KG (2015) Evaluation of the protective effect of Pterocarpus marsupium on acetic acid-induced ulcerative colitis in rats. Inflammopharmacology 23(4) 195-201.

26. Hougee S, Faber J, Sanders A, De Jong RB (2005) Selective COX-2 inhibition by a Pterocarpus marsupium extract characterized by pterostilbene, and its activity in healthy human volunteers. Planta Med 71: 387-392.

27. Bose SN, Sepaha GC (1956) Clinical observations on the antidiabetic properties of Pterocarpus marsupium and Eugenia jambolana. Ind Med Assoc 27(11): 388-391.

28. Jahromi MF, Ray AB, Chansouria JPN (1993) Antihyperlipidemic effect of flavonoids from Pterocarpus marsupium. J Nat Prod 56 (7): 989-994.

29. Manickam M, Ramanathan M, Farboodniay Jahromi MA, Chansouria JPN, Ray AB (1997) Antihyperglycemic activity of phenolics from Pterocarpus marsupium. J Nat Prod 60 (6): 609-610.

30. Devipriya D, S Gowri, TR Nideesh (2007) Hepatoprotective effect of Pterocarpus marsupium against carbon tetrachloride induced damage in albino rats. Anc Sci Life 27(1): 19-25.

31. Mohire NC, Salunkhe VR, Bhise SB, Yadav AV (2007) Cardiotonic activity of aqueous extract of heartwood of Pterocarpus marsupium 45 (6): 532-537.

32. Karanjit N, Shrestha UK, Ranjitkar RR (2008) A study on hypoglycemic properties of Pterocarpus marsupium Roxb. Bullet Dept Plant Res 30 97-101.

33. Badkhane Y, Yadav AS, Sharma AK, Raghuwanshi DK, Uikey SK, et al. (2010) Pterocarpus marsupium Roxb-Biological activities and medicinal properties. Int J Adv Pharm Sci 1 (4).

34. Patil UH, Dattatraya KG (2011) Pterocarpus marsupium: a valuable medicinal plant in diabetes management. Int J App Bio Pharm Tech 2 6-13.

35. Waghmare AS, Waghmare PD, Grampurohit ND, Gadhave MV (2012) Free radical scavenging activity of methanolic and aqueous extract of Pterocarpus marsupium heartwood by DPPH method. J Sci Res Phar 1: 89-91.

36. Rizvi SI, Mishra N (2013) Traditional Indian medicines used for the management of diabetes mellitus. J Diabetes Res: 712092.

37. Khan MY, Aziz I, Bihari B, Kumar H, Roy M (2014) A review- Phytomedicines used in treatment of diabetes. Diabetes 101: 126.

38. Hilal A, Kalyanaraman R (2015) Pharmacology of Pterocarpus marsupium Roxb. Med Plant Res 5: 1-6.

39. Pradhan S, Sahu SK, Panda SK, Mishra SS, Chinara PK (2017) Hypoglycaemic effect of Pterocarpus marsupium. Journal of the Anatomical Society of India 66: S42.

40. Singh P, Bajpai V, Gupta A, Gaikwad AN, Maurya R, et al. (2019) Identification and quantification of secondary metabolites of Pterocarpus marsupium by LC-MS techniques and its in-vitro lipid lowering activity. Industrial Crop Products 127: 26-35.
41. Haranath PS, Ranganatha Rao K, Anjaneyulu CR, Ramanathan JD (1958) Studies on the hypoglycemic and pharmacological actions of some stilbenes. Indian J Med Sci 12: 85-89.

42. Mitra J, T Joshi (1982) An isoflavone glycoside from the heartwood of Pterocarpus marsupium. Phytochemistry 21(9): 2429-2430.

43. Adinarayana D, Syamasundar KV (1982) A new sesquiterpene alcohol from Pterocarpus marsupium. Phytochemistry 21(5): 1083-1085.

44. Chakravarthy BK, Gode KD (1985) Isolation of (-)-Epicatechin from Pterocarpus marsupium and its Pharmacological Actions. Planta Med 51(1): 56-59.

45. Tripathi J, Joshi T (1988) Phytochemical investigation of roots of Pterocarpus marsupium. Isolation and structural studies of two new flavanone glycosides. Z Naturforsch C 43(3-4): 184-186.

46. Mohan P, Joshi T (1989) Two aurone glycosides from the flowers of Pterocarpus marsupium. Phytochemistry 28(4): 1287-1288.

47. Jain SC, Sharma SK, Kumar R, Rajwanshi VK, Babu BR (1997) A homoisoflavanone from Pterocarpus marsupium. Phytochemistry 44(1): 765766.

48. Mathew J, Subba Rao AV (1983) Carpusin: a novel 2-hydroxy-2-benzylcoumaranone from Pterocarpus marsupium. Phytochemistry 22(3): 794-795.

49. Yadav RK, Singh RK (1998) 6-hydroxy-3,5,7,4'-tetramethoxyflavone 6-rhamnoside from roots of Pterocarpus marsupium. Phytochemistry 48(7): 1259-1261.

50. Handa SS, Singh R, Maurya R, Satti NK, Suri KA, et al. (2000) Pterocarposide, an isoaurone $C$-glucoside from Pterocarpus marsupium. Tetrahedron Letters 41: 1579-1581.

51. Maurya R, Singh R, Deepak M, Handa SS, Yadav PP, et al. (2004) Constituents of Pterocarpus marsupium: an ayurvedic crude drug. Phytochemistry 65(7): 915-920.

52. Anandharajan R, Pathmanathan K, Shankernarayanan NP, Vishwakarma RA, Balakrishnan A (2005) Upregulation of Glut-4 and PPAR gamma by an isoflavone from Pterocarpus marsupium on L6 myotubes: a possible mechanism of action. J Ethnopharmacol 97(2): 253-260.

53. Wu SF, Hwang TL, Chen SL, Wu CC, Ohkoshi E, et al. (2011) Bioactive components from the heartwood of Pterocarpus santalinus. Bioorganic and Medicinal Chemistry Letters 21 (18): 5630-5632.

54. Thara KM, Zuhara F, Raji TK (2013) Inhibitory and synergistic effect of Pterocarpus marsupium extracts on clinical and standards strains of microorganisms and its biochemical analysis. Indo Am J Pharm Res 3: 5583-5596.

55. Joshi KR, Devkota HP, Yahara S (2014) Bijayasaline: a new C-glucosyl-alpha-hydroxy dihydrochalcone from the heartwood of Bijayasal (Pterocarpus marsupium). Nat Prod Commun 9(6): 821-822.

56. Majeed M, Bani S, Natarajan S, Pandey A (2017) Evaluation of 90-day repeated dose oral toxicity and reproductive/developmental toxicity of 3'-hydroxypterostilbene in experimental animals. PLoS One 12(3): e0172770. 
(C) This work is licensed under Creative

BY DOI: 10.19080/JCMAH.2019.09.555754

\section{Your next submission with Juniper Publishers will reach you the below assets}

- Quality Editorial service

- Swift Peer Review

- Reprints availability

- E-prints Service

- Manuscript Podcast for convenient understanding

- Global attainment for your research

- Manuscript accessibility in different formats ( Pdf, E-pub, Full Text, Audio)

- Unceasing customer service

Track the below URL for one-step submission https://juniperpublishers.com/online-submission.php 